\title{
Caso radiológico para diagnóstico
}

\section{Drs. Michael Hirsch $\mathbf{S}^{(1)}$, Oscar Ardiles $C^{(2)}$, Mario Mora $\mathbf{V}^{(3)}$, Gonzalo Pereira $\boldsymbol{R}^{(4)}$.}

1. Residente de Radiología, Centro de Imagenología. Hospital Clínico Universidad de Chile.

2. Médico en pasantía de capacitación, Centro de Imagenología. Hospital Clínico Universidad de Chile.

3. Radiólogo, Departamento de Diagnóstico por Imágenes. Hospital Militar de Santiago. Chile.

4. Radiólogo Unidad de Tórax, Centro de Imagenología. Hospital Clínico Universidad de Chile.

\section{Historia clínica}

Paciente de 27 años, sexo femenino, sin antecedentes mórbidos personales relevantes. Consulta en el Servicio de Urgencia del Hospital Clínico de la Universidad de Chile por dolor torácico progresivo de 4 días de evolución, con puntada de costado a izquierda. No presenta tos, expectoración ni fiebre; se objetiva polipnea leve y el resto de sus signos vitales dentro de parámetros normales. No hubo hallazgos relevantes al examen físico.

El estudio de laboratorio inicial fue normal a excepción del dímero D, cuyo valor fue de $3.074 \mathrm{ng} / \mathrm{ml}$. Se solicitó radiografía de tórax y posteriormente AngioTC (Figuras 1, 2 y 3).

Además del tromboembolismo pulmonar:

\section{¿Cuál es el diagnóstico?}

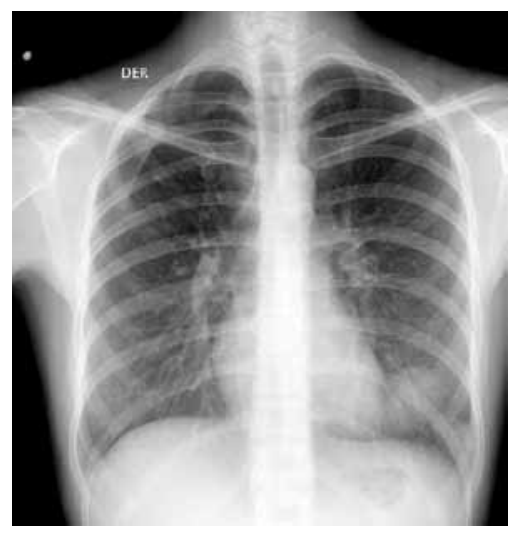

Figura 1.

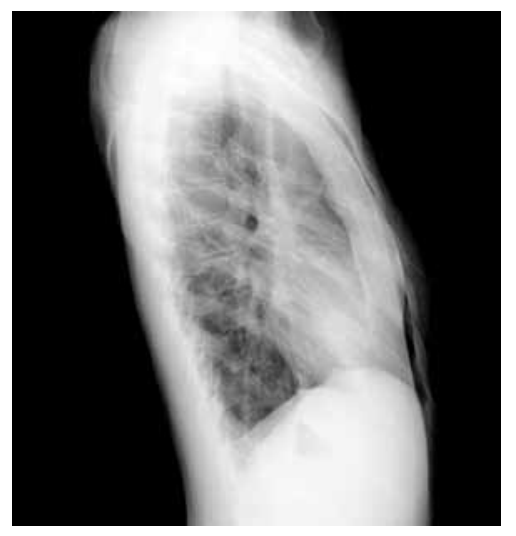

Figura 2.

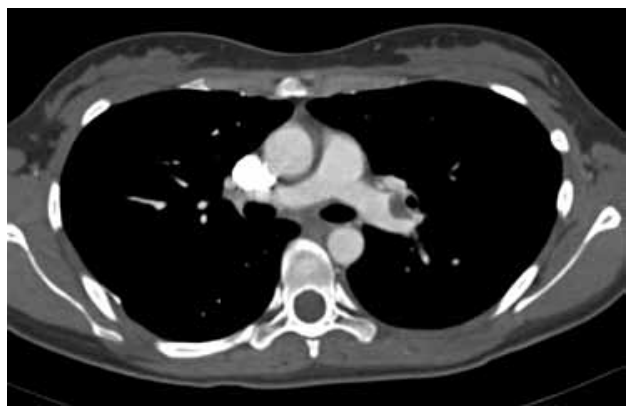

Figura 3. 